\title{
ОСОБЕННОСТИ ПАТОМОРФОГЕНЕЗА ЛИМФОИДНОГО ЛЕЙКОЗА У КУР
}

\section{T.I. Vakhrusheva}

\section{THE PECULIARITIES OF PATHOMORPHOGENESIS OF LYMPHOID LEUKEMIA IN CHICKENS}

Вахрушева Татьяна Ивановна - канд. ветеринар. наук, доц. каф. анатомии, патологической анатомии и хирургии Красноярского государственного аграрного университета, г. Красноярск. E-mail:vlad_77.07@mail.ru

Изучена патоморфологическая картина изменений органов и тканей у кур при лимфоидном лейкозе, установлены характерные патогномоничные для основного заболевания макро- $u$ микроскопические изменения, проведена дифференциальная диагностика от патологии со сходными морфологическими признакам - болезни Марека. Объектами исследования являлись петухи и куры-несушки, содержащиеся в одном из фрермерских хозяйств Красноярского края, в течение 2019 г. было проведено патолого-анатомическое вскрытие 11 трупов птии. Проводился забор материала для гистологического исследования - фррагменты тканей фрабрициевой бурсы, селезенки, печени, почек, сердца, тонкого и толстого отделов кишечника, легких, яичника, яйцевода, семенников, срезы изготавливались на микротоме «Техном МЗП01», окрашивались гематоксилином Эрлиха и эозином. Для проведения серологических исследований сыворотки крови кур на наличие антител к ALV-A проводился забор крови от птиц с клиническими признаками болезни - 10 голов, специфические антитела выявлялись во всех случаях в реакции ИФА. Для проведения дифрференциальной диагностики в лабораторию отправлялся патолого-анатомический материал, инфрекция была исключена во всех случаях. Результаты изучения органов и тканей показали, что причиной гибели птии стал хронический лимфоидный лейкоз. Ведущую роль при посмертной патоморфологической диагностике играет комплексная оценка как патологоанатомических и патогистологических, так и анамнестических данных, при этом основополагающими критериями в постановке диагноза являются возраст птицы старше 12 месяцев,
Vakhrusheva Tatyana Ivanovna - Cand. Veterinary Sci., Assoc. Prof., Chair of Anatomy, Pathological Anatomy and Surgery, Krasnoyarsk State Agrarian University, Krasnoyarsk.

E-mail: vlad_77.07@mail.ru

хроническое течение, отсутствие нервных явлений в анамнезе, увеличение размеров печени при клиническом осмотре, выявление опухолевых разрастаний в фабрициевой бурсе, печени, почках, спленомегалия и клеточный состав опухолевых инфильтратов, представляющих собой очаги пролифрерации слабодиффференцированных лимфоидных клеток. Полученные данные позволят оптимизировать процесс комплексной диагностики лимфоидного лейкоза птии, в том числе дифрференциальной.

Ключевые слова: куры, лимфоидный лейкоз, гемобластозы, В-клеточная лимфома, лимфобластоз, лимфоолейкоз, болезни птицы, болезнь Марека.

Pathomorphological picture of changes in organs and tissues in chickens, with lymphoid leukemia was studied, characteristic pathognomonic macro- and microscopic changes for underlying the disease were established and differential diagnosis of the disease with similar morphological signs - Marek's disease was performed. The objects of the study were roosters and laying hens kept in one of the farms of Krasnoyarsk Territory, during 2019 an autopsy was performed on 11 birds' corpses. The material was taken for histological examination - tissue fragments of the bursa, spleen, liver, kidneys, heart, small and large intestines, lungs, ovary, oviduct, testes, sections were made on "Tekhnom MZP-0" microtome, stained with Ehrlich hematoxylin and eosin. To conduct serological studies of hens' blood serum for the occurrence of antibodies to ALV-A, blood samples were taken from the hens with clinical signs of the disease - 10 birds, specific antibodies were detected in all the cases in enzyme-linked immunosorbent assay (ELISA). For making differen- 
tial diagnosis, pathological and anatomical material was sent to the laboratory, the infection was excluded in all the cases. The results of organs and tissues study showed that chronic lymphoid leukemia had been the cause of the birds' death. Leading role in post-mortem pathomorphological diagnosis was played by comprehensive assessment of both macroscopic and histological and medical case data, while fundamental criteria in the diagnosis were the age of the poultry older than 12 months, chronic course, the absence of nervous phenomena in the anamnesis, the increase in liver size during clinical examination, and identification tumor growths in the bursa, liver, kidneys, splenomegaly and cellular composition of tumor infiltrates, which were the foci of proliferation and poorly differentiated lymphoid cells. The data obtained will help to optimize the process of complex diagnostics of lymphoid leukemia in the poultry, including differential.

Keywords: hens, lymphoid leukemia, hemoblastoses, B-cell lymphoma, lymphoblastosis, lymphocytic leukemia, diseases of the poultry, Marek's disease.

Введение. Лимфоидный лейкоз (лимфобластоз, лимфолейкоз, В-клеточная лимфома) наиболее часто встречающаяся форма лейкоза у птиц, которая обнаруживается у более чем $80 \%$ от общего количества случаев заболеваний лейкозом. Болезнь протекает хронически и регистрируется преимущественно у кур в возрасте 6-16 месяцев [1, 2]. Возбудитель Вклеточной лимфомы - вирус лейкоза птиц (ВЛП) подгруппы А, который первично развивается в тканях фабрициевой бурсы, поражая ее и индуцируя метастазирование опухолевых клеток в висцеральных органах - примущественно в печени, селезенке, почках. Заболевание широко распространено во многих странах мира, в том числе на территории Российской Федерации, нанося птицеводству значительный экономический ущерб $[1,3]$. Основной мерой борьбы с лимфоидным лейкозом является ранняя диагностика с выявлением больных особей и последующей их выбраковкой, при этом решающую роль в постановке диагноза играет патоморфологическое исследование всей павшей и вынужденно убитой птицы, включая обязательное проведение гистологического анализа патологоанатомического материала $[1,4,5]$. При этом рядом авторов отмечается значительное сходство как макро-, так и микрокартины лейкозных пролифератов с новообразованиями нелейкоз- ного характера. Особое значение среди заболеваний патоморфологически сходных с лимфоидным лейкозом отводится болезни Марека (нейролимфоматозу), которое в последние десятилетия имеет более широкое распространение и, в отличие от лейкоза, вызывается герпесвирусом группы В, поражает птицу более раннего возраста - 60-180 суток, а клеточный состав опухолевых образований отличается тем, что клетки лимфоидного ростка сохраняют способность к диффреренциации [5].

Учитывая широкое распространение вируса лимфоидного лейкоза (ALV-A) среди поголовья кур, разводимого на птицефабриках Российской Федерации, а также необходимость совершенствования методов диагностики, в том числе дифференциальной, изучение патоморфологической картины данного заболевания у кур является актуальной задачей [6-8].

Цель исследования. Анализ картины патоморфологических изменений и дифференциальная диагностика лимфоидного лейкоза у кур с установлением патогномоничных признаков основного заболевания.

Материалы и методы. Объектом исследования являлись куры-несушки и петухи, содержащиеся в одном из фермерских хозяйств Красноярского края. В течение 2019 г. было проведено патолого-анатомическое вскрытие 11 трупов вынужденно убитой птицы в возрасте от 14 до 15 месяцев - 9 кур, 2 петуха породы Леггорн кросса Хайсекс Браун. Во время вскрытия проводился забор материала для гистологического исследования - фрагменты тканей фабрициевой бурсы, селезенки, печени, почек, сердца, тонкого и толстого отделов кишечника, легких, яичника, яйцевода, семенников. Патологоанатомический материал фиксировался в 10\% нейтральном растворе фрормалина, срезы изготавливались на микротоме «Техном МЗП-01», окрашивались гематоксилином Эрлиха и эозином, микроскопия проводилась на микроскопе «Levenhuk 320». Микрофотосъемку и анализ микрофотографий проводили на фотоаппарате Canon EOS 1100D. Для проведения серологических исследований сыворотки крови кур на наличие антител к ALV-A проводился забор крови от птиц с клиническими признаками болезни 10 голов, материал отправлялся в КГКУ Красноярский отдел ветеринарии, специфические антитела выявлялись во всех случаях в реакции ИФА. Для проведения дифференциальной диагностики в лабораторию отправлялся патолого- 
анатомический материал - фрагменты тонкого отдела кишечника, кусочки печени, почек, легких, селезенки, при лабораторном исследовании инфекция была исключена во всех случаях.

Результаты исследования и их обсуждение. При исследовании данных анамнеза больной и павшей птицы установлено, что куры содержались в отдельном помещении, тип содержания - напольный, тип кормления - концентратный. Первые клинические признаки наблюдались у птицы в возрасте 12-13 месяцев, при этом у кур отмечались вялость, сонливость, снижение аппетита и живой массы тела, цианоз, сухость и бледность гребешков и бородок, эпизодически возникающая диарея, снижение яйценоскости на 60-70 \% в первые 30-45 суток, далее у $30 \%$ больной птицы отмечалось полное прекращение яйцекладки.В возрасте 14-15 месяцев у $70 \%$ больной птицы выявлялись признаки асцита - характеризующиеся значительным увеличением объемы грудобрюшной полости, больные особи принимали характерную «позу пингвина», при пальпаторном исследовании обнаруживалось значительное увеличение размеров печени, границы которой выступали за край реберной дуги. При этом отсутствовали признаки изменения глаз - цвета радужной оболочки («сероглазости») и формы зрачка, что является важным критерием при дифференциальной диагностике лейкоза птиц от болезни
Марека. Для лечения больной птицы использовалась схема, включающая антибиотики, противогрибковые средства, комплексные витаминноминерально-аминокислотные кормовые добавки. Применяемое лечение не являлось эфффективным, симптомы основного заболевания проявлялись вновь через 10-14 суток после улучшения и прогрессировали, вследствие чего вся больная птица была подвергнута вынужденному убою.

При секции трупов птицы у всех птиц при наружном осмотре выявлялась картина кахексии различной степени выраженности, общей хронической застойной гиперемии видимых слизистых и кожных покровов, особенно в области головы, у $54 \%$ особей выявлялись признаки диареи и умеренного обезвоживания тканей (рис. 1).

При внутреннем осмотре трупов птиц обнаруживались макроскопические признаки как очагового, так и смешанного (узелкового в сочетании с дифффузным) поражения органов и тканей: фабрициевой бурсы, печени, селезенки, почек. При этом, вне зависимости от формы поражения, выявлялась резко выраженная асимметрия патологически измененных органов. Признаки асцита выявлялись у всех трупов и характеризовались скоплением в грудобрюшной полости значительного количества (от 57 до 120 мл) прозрачной соломенного цвета жидкости (рис. 2).

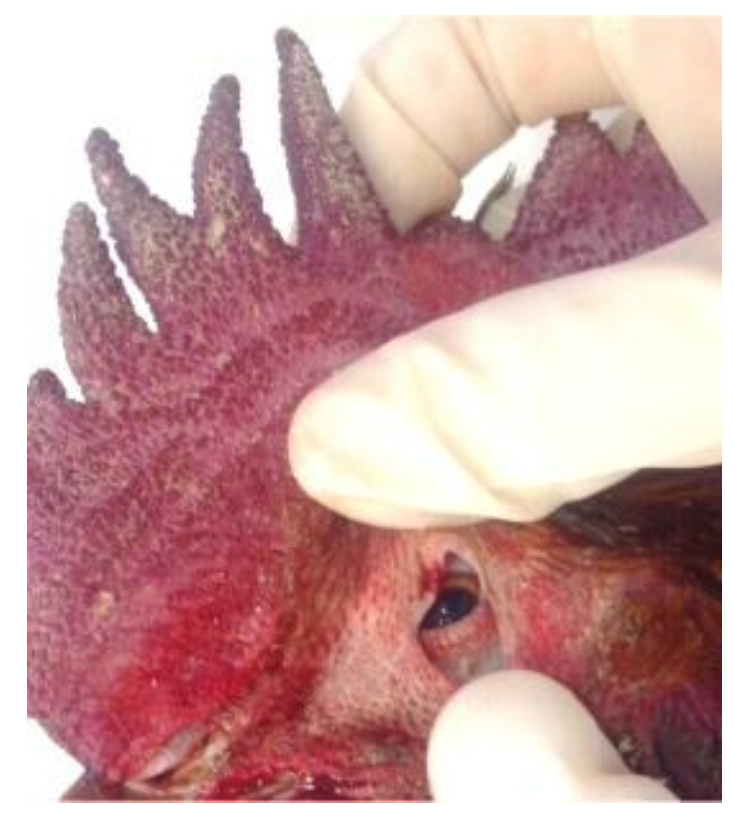

Puc. 1. Цианоз гребня и отсутствие изменений тканей глазного яблока у птицы 


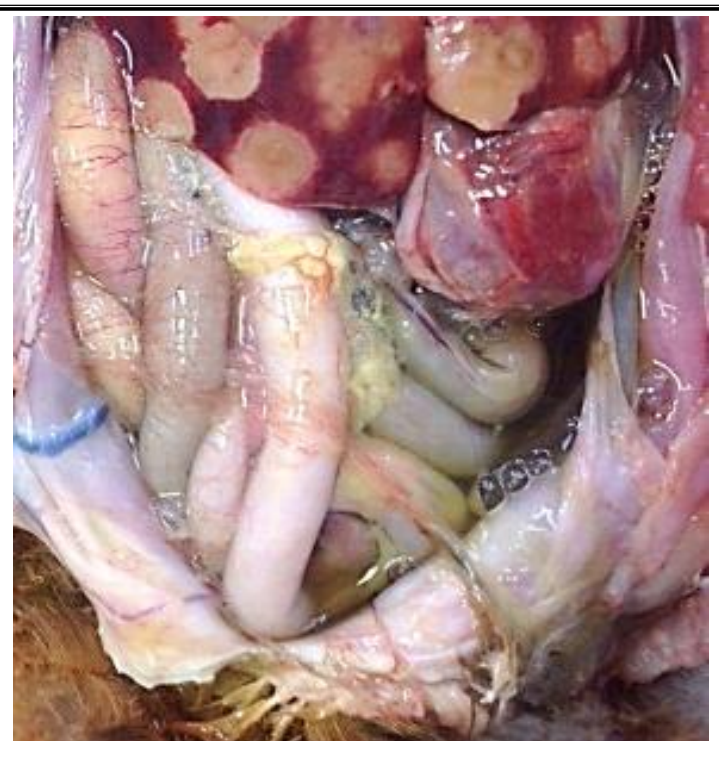

Puc. 2. Грудобрюшная полость: скопление отечного выпота, спайки петель кишечника

При гистологическом исследовании в пораженных органах и тканях выявлялись обширные очаговые или дифффузные пролифераты, состоящие из бластных форм лимфоцитов, преимущестенно лимфобластов и пролимфоцитов, клеток округлой формы, с крупным ядром с тонкой сетчатой структурой и наличием от одного до трех ядрышек, часто расположенных несколько эксцентрично, узким пояском относительно светлой базофильной цитоплазмы. Источником опухолевых клеток является фрабрициева бурса, которая поражается в самом начале болезни, в дальнейшем неоплазменная ткань метастазирует с образованием опухолевых очагов в висцеральных органах.

У всех больных птиц, вне зависимости от возраста и пола, устанавливались резко выраженные изменения фабрициевой бурсы - центрального органа иммунопоэза птиц, который в условиях фризиологической нормы подвергается возрастной инволюции в период достижения ею половой зрелости, в среднем в 6-9 месяцев. У 27 \% трупов отмечалась узелковая форма поражения - клоакальная сумка была увеличена, достигая размеров 1,9×24 см, плотной консистенции, на разрезе в ткани органа выявлялись множественные участки новообразований серобелого цвета, однородной «саловидной» структуры. У 73 \% птиц обнаруживалось диффузное поражение фабрициевой бурсы, характеризовавшееся значительным увеличением объема органа до 2,5×3,5 cм, с вовлечением в неопластический процесс обширных участков ткани органа и образованием массивного новообразования, с его уплотнением или размягчением на поздних стадиях процесса у 36 \% исследуемых трупов (рис. 3).

Гистологически в ткани органа обнаруживались значительные изменения архитектоники множественные очаги пролифератов, состоящие из бластных форм лимфоцитов, замещают фолликулы фабрициевой бурсы, при этом пораженные фолликулы вытесняют и сдавливают физиологически нормальную ткань, у 45 \% наблюдалось полное замещение ткани органа неопластическими клетками.

В $100 \%$ случаев проведенного вскрытия обнаруживались выраженные изменения в ткани печени в виде резкого увеличения органа в размерах и нарушения топографии, а также наличия множественных опухолевых очагов неправильной округлой формы желто-серого цвета, различного размера от 0,2 до 3,5 cм, на разрезе однородных, плотной консистенции, имеющих тенденцию к слиянию. Ткань печени - серокрасного или серо-желтого цвета, с выраженным синюшным оттенком, сосуды - повышенно кровенаполнены (рис. 4, 5). 


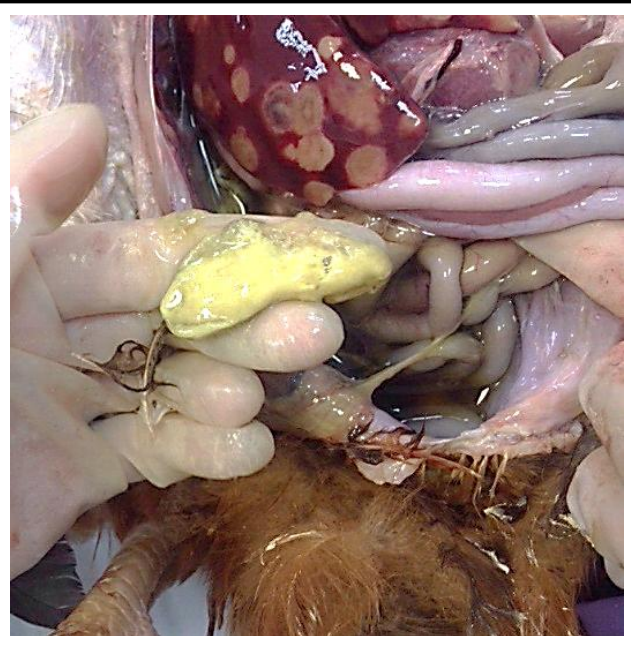

Puс. 3. Фабрициева бурса курицы: тотальное замещение ткани органа неопластическими разрастаниями со значительным размягчением

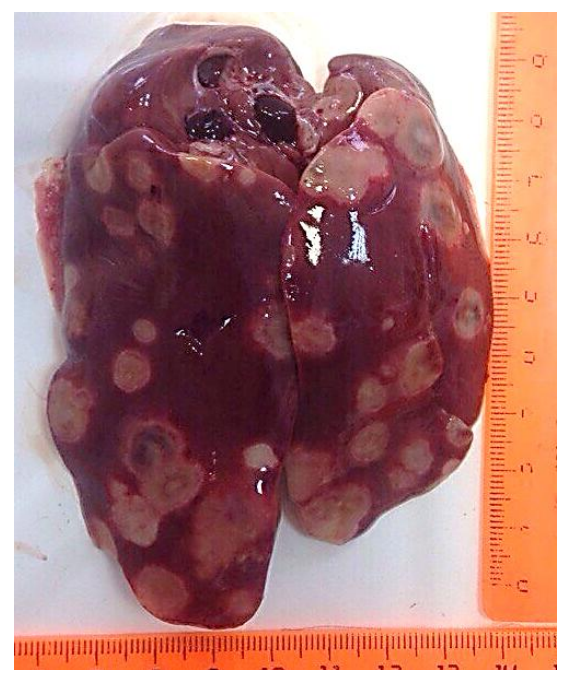

Puс. 4. Печень курицы: множественные очаги лейкозных пролифератов

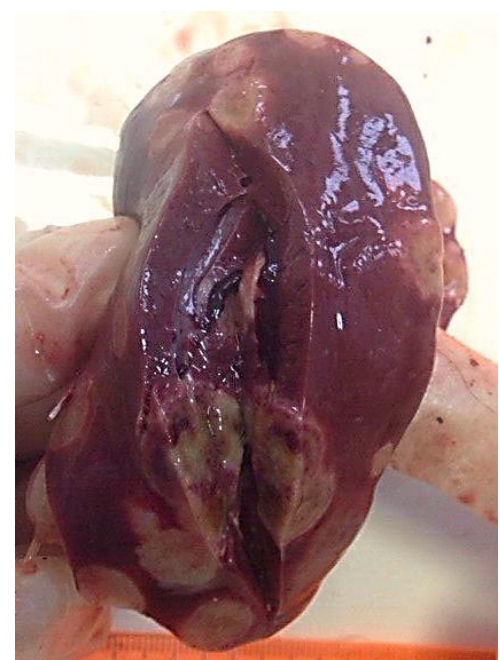

Puc. 5. Печень курицы (орган на разрезе): очаги лейкозных пролифератов, пассивная гиперемия, белковая дистрофия 
Гистологические изменения печени характеризовались наличием множественных очагов пролифератов бластных форм широкоплазменных лимфоидных клеток, локализующихся как в интерстициальной ткани портальных трактов, так и в различных участках долек печени, формируя конгломераты различных размеров, которые, сливаясь, образуют крупные неопластические очаги, окруженные на периферии ободком из псевдоэозинофииььных лейкоцитов, вытесняющие нормальную ткань органа, при этом участки некрозов как в очагах пролиферации опухолевых клеток, так и в печеночных дольках отсутствуют, что является важным признаком в дифференциальной диагностике лимфоидного лейкоза от болезни Марека (рис. 6, 7). Агрегаты опухолевых клеток выявляются в просветах портальных сосудов, в периваскулярных пространствах, а также в просветах синусоидных капилляров. Клетки печени - с признаками умеренной и глубокой белково-жировой дегенерации, также выявлялись признаки очаговодифффузного венозно-капиллярного полнокровия, расширение и гиперемии пространств Диссе (рис. 7).

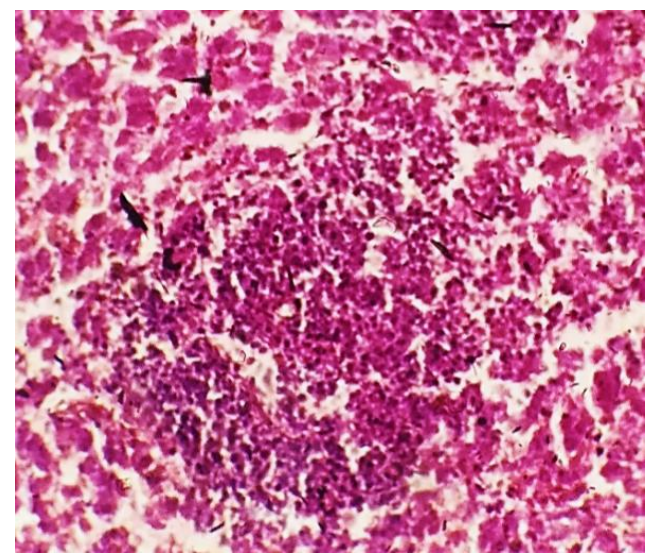

Puc. 6. Печень курицы: скопление бластных фрорм лимфоцитов в ткани дольки, зернисто-жировая дистрофия гепатоцитов (окраска гематоксилином и эозином; × 400)

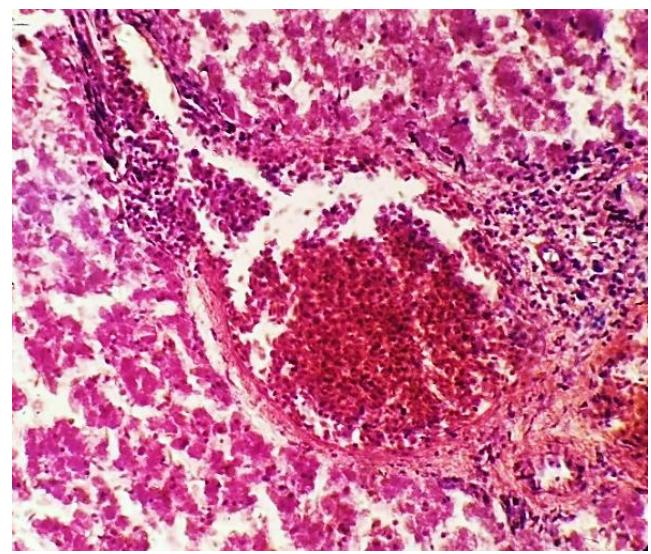

Puc. 7. Печень курицы: инфильтрация периваскулярных пространств лимфобластами и пролимфоцитами, резкое полнокровие портальных вен

(окраска гематоксилином и эозином; $\times 400$ )

Патоморфологические изменения селезенки характеризовались у трупов всех исследуемых птиц (100 \%) признаками выраженной спленомегалии, при этом размеры органа варьировали от 2,8 до 3,5 см, а также острой застойной гиперемии и наличием в ткани органа единичных и множественных мелких геморрагий. У 27 \% птиц выявлялись специфические очаги лейкозных 
разрастаний в виде участков серо-белого цвета неправильной формы размерами от 0,3 до 0,85 см (рис. 8). Гистологически выявлялось резко выраженное нарушение тканевого строения за счет инфильтрации ткани бластными формами клеток лимфоидного ряда, как в области красной, так и белой пульпы. При очаговой форме наибольшее количество неопластических клеток выявлялось в зоне локализации периартери- альных лимфатических влагалищ и лимфатических узелков, которые, захватывая более обширные площади, пролиферируют в перифолликулярную зону и пульпарные тяжи, в некоторых случаях полностью замещая красную пульпу (рис. 9). Синусы красной пульпы расширены, содержат конгломераты неопластических клеток (опухолевые эмболы).

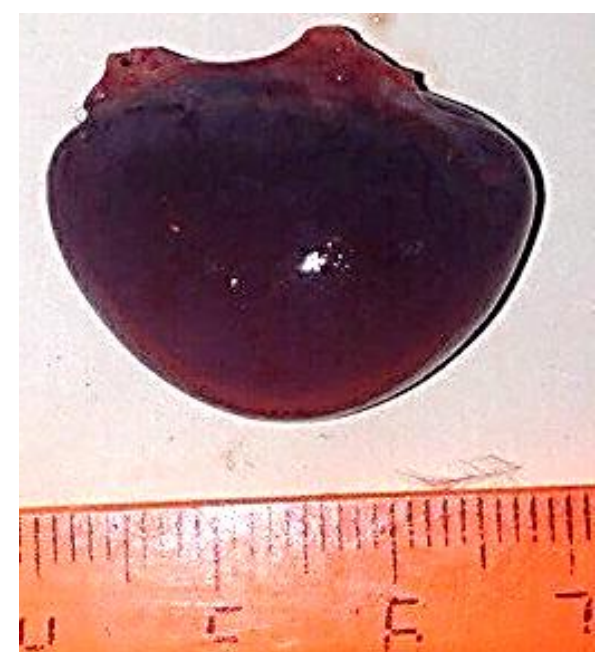

Puc. 8. Селезенка курицы: острая застойная гиперемия, спленомегалия

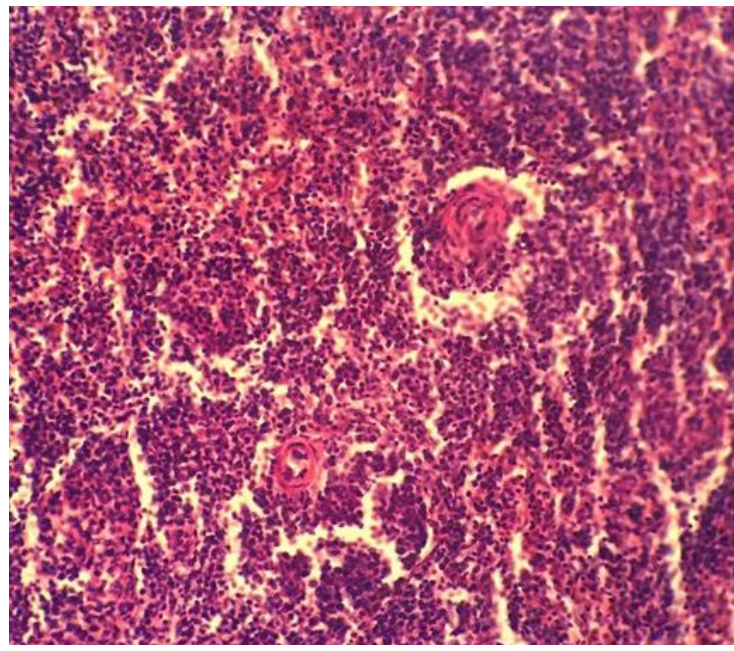

Puc. 9. Селезенка курицы: инфильтрация ткани белой и красной пульпы бластными формами лимфоидных клеток (окраска гематоксилином и эозином; × 400)

Патоморфологическая картина почек характеризовалась очаговыми и диффузными поражениями органов, у трех птиц выявлялась смешанная фрорма поражений. В ткани почек наблюдались как множественные очаги лейкозных пролифератов, так и диффузное разрастание неопластической ткани, сопровождающееся резким увеличением органа в объеме, а также выраженной белково-жировой дегенерацией эпителиоцитов канальцев и картиной острой застойной гиперемии (рис. 10, 11). 


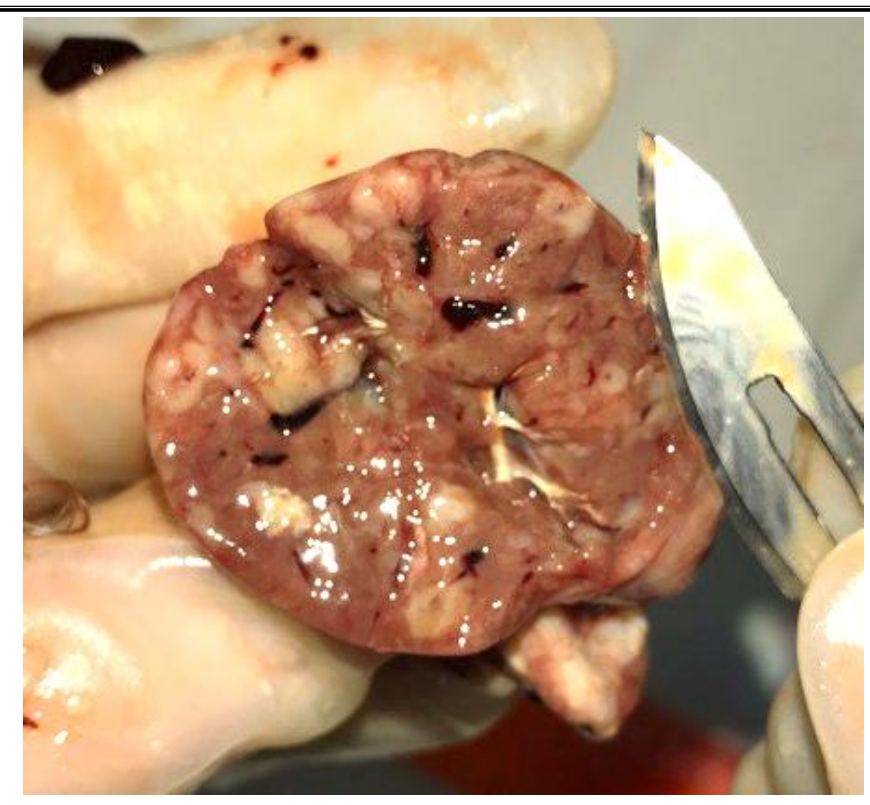

Puс. 10. Почка курищы: очаги лейкозных пролифератов, зернисто-жировая дистрофия

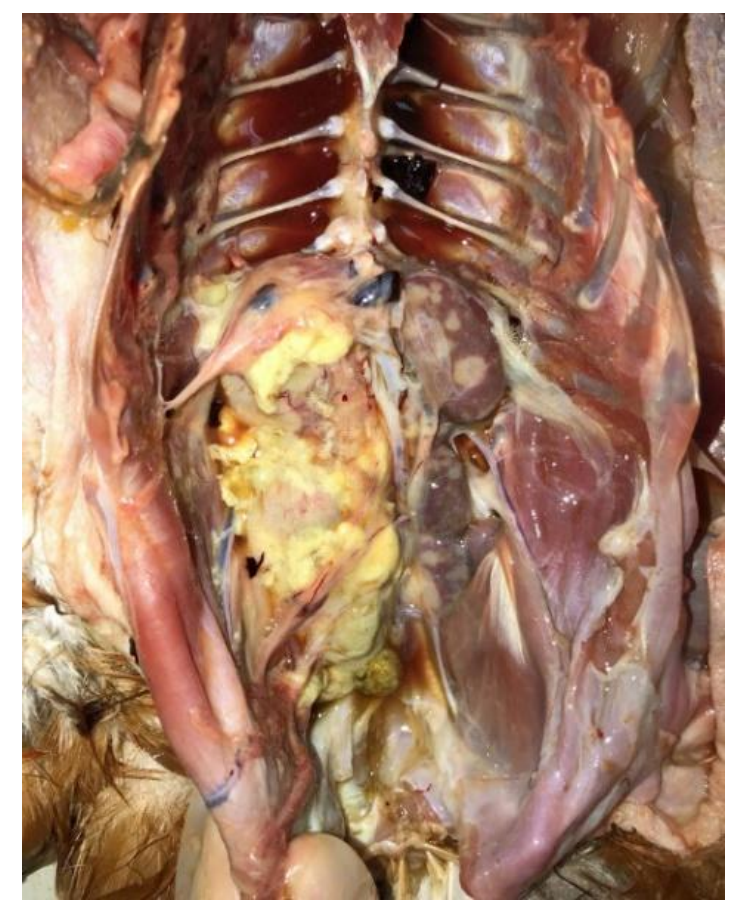

Puс. 11. Почки курицы: дифффузная фрорма разрастания неопластической ткани в правой почке

При гистологическом исследовании в ткани почек выявлялось острое очаговое венознокапиллярное полнокровие с эритростазами и диапедезными кровоизлияниями. Сосудистые клубочки почечных телец - сжаты, деформированы, полости капсул Боумена-Шумлянского расширены, заполнены глыбчатым эозинофильным содержимым. Просветы канальцев резко сужены, в них выявляются слущенные клетки эпителия и эозиносильные белковые массы, эпителиоциты канальцев почек в состоянии тотальной зернисто-жировой дистрофии с некробиозами-некрозами вследствие компрессии лейкозными пролифератами, которые, располагаясь преимущественно в интерстиции органа, имеют выраженную тенденцию к слиянию и росту, вызывая атрофию паренхиматозных элементов (рис. 12, 13). 


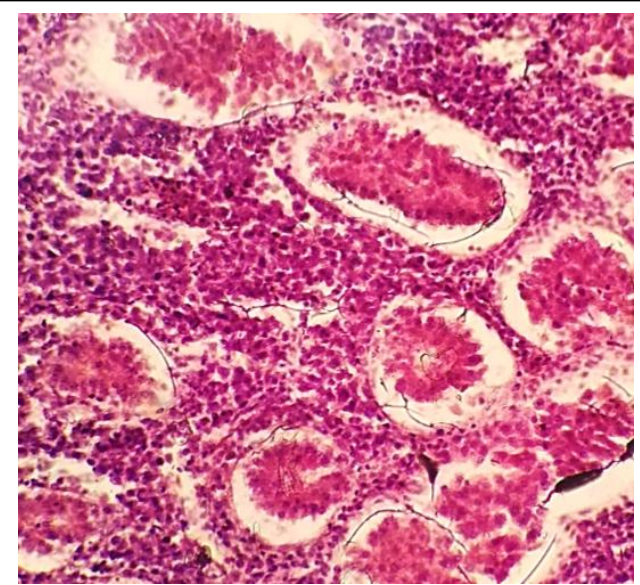

Puc. 12. Почки курицы: пролифрерация неопластических клеток в межуточной ткани почек, дегенерация эпителиоцитов канальцев (окраска гематоксилином и эозином; × 400)

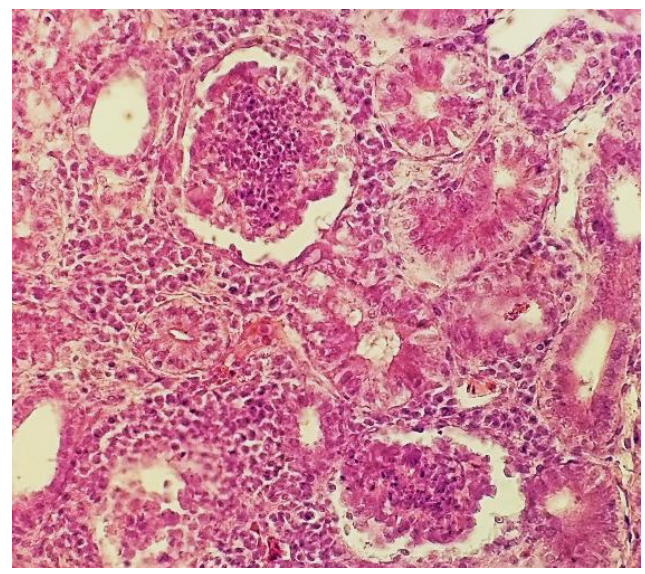

Puc. 13. Почки курицы: дефрормация почечных телец, расширение полости капсул БоуменаШумлянскаго (окраска гематоксилином и эозином; × 400)

Патоморфологические исследования легких лись у 45,5 \% птиц и представляли собой очаги птицы показали, что лейкозные разрастания, неправильной фрормы желто-коричневого цвета, видимые невооруженным глазом, обнаружива- без четких границ (рис. 14).

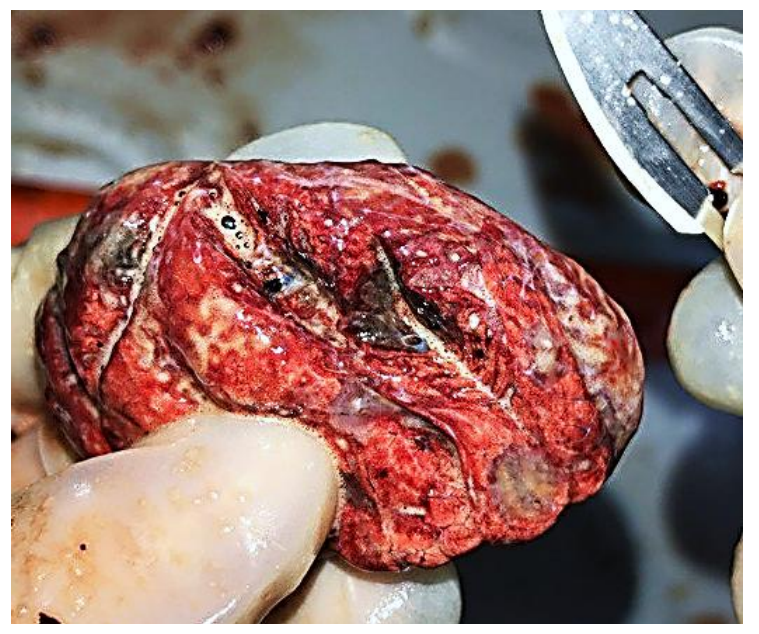

Puc. 14. Легкие курищы: очаги лейкозных пролифератов 
При исследовании гистологической картины в легких всех птиц обнаруживались обширные очаги дифффузных разрастаний неопластических клеток, состоящие преимущественно из слабодифференцированных форм лимфоцитов и незначительного количества агрегатов псевдоэозинофильных лейкоцитов на периферии, инфильтрирующие как перибронхиальную, так и соединительную ткань долек легкого и стенки воздухоносных капилляров, обуславливая их значительное утолщение и сужение полостей межкапиллярных воздухоносных протоков. В ткани органа выявляются признаки дифффузного венозно-капиллярного полнокровия, в просветах сосудов обнаруживаются опухолевые эмболы (рис. 15, 16).

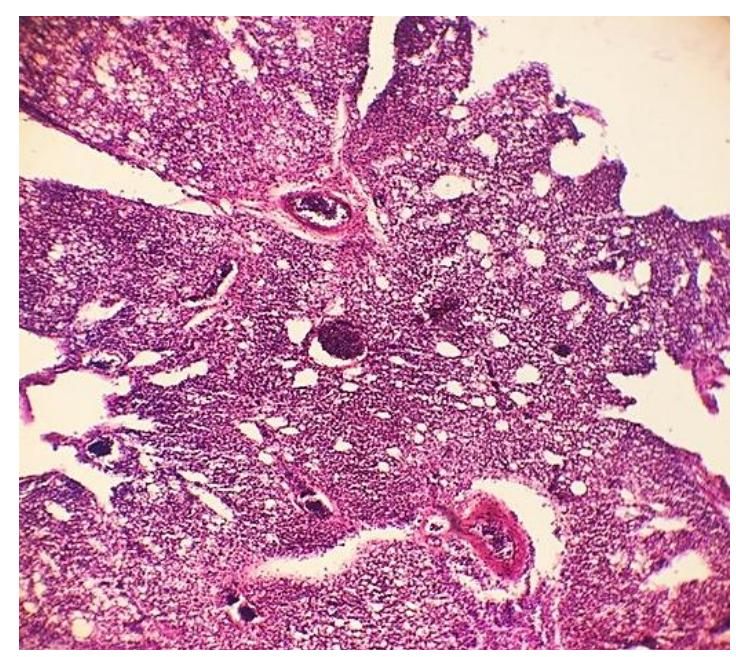

Puc. 15. Легкие курицы: дифффузная пролиферация неопластических лимфоидных клеток в ткани дольки (окраска гематоксилином и эозином; × 100)

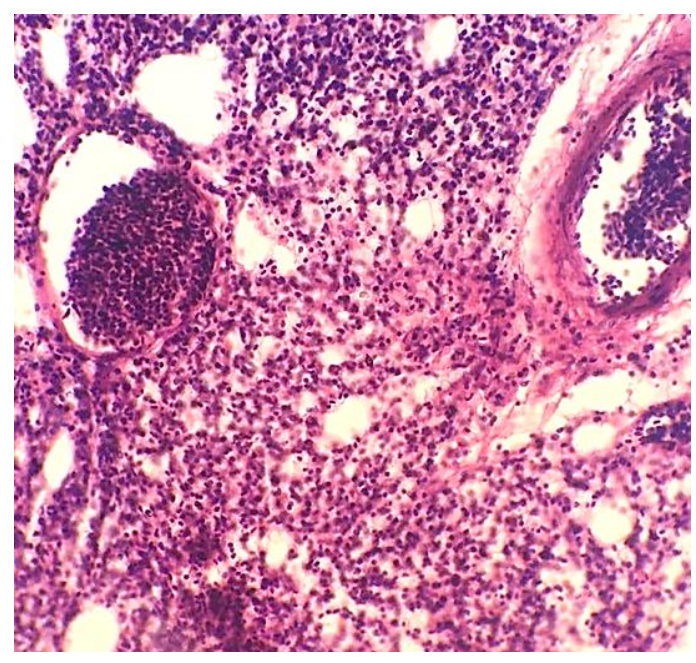

Puс. 16. Легкие курицы: пролиферация лимфобластов в стенках воздухоносных капилляров, опухолевые эмболы в просветах сосудов (окраска гематоксилином и эозином; × 400)

При макроскопическом исследовании тканей кишечника у 100 \% трупов птиц выявлялись изменения, характерные для острого и подострого катарального или серозно-катарального гастроэнтероколита, специфическими для лейкоза изменениями являлись значительное утолщение стенки кишечника - в 1,5-2 раза, ее ригидность, окрашивание в бело-желтый цвет, у 72 \% птиц в слизистой оболочке обнаруживались множественные диапедезные кровоизлияния (рис. 17). У $18 \%$ трупов выявлялись очаговое поражение кишечника и брыжейки в виде множественных опухолевых узелков различного размера, имеющих тенденцию к слиянию. В 27 \% случаев 
вскрытия выявлялись опухолевые спайки петель с образованием бугристых конгломератов серо-белого цвета плотной консистенции.

Гистологическая картина характеризовалась диффузной инфильтрацией ворсинок лимфобластами, их значительным утолщением и деформацией, а также слизистой дистрофией и тотальной десквамацией эпителия, острым венозно-капиллярным полнокровием сосудов подслизистой основы и мышечной оболочки с эритростазами и диапедезными микрогеморрагиями, в просветах сосудов обнаруживались лейкозные эмболы (рис. 18).

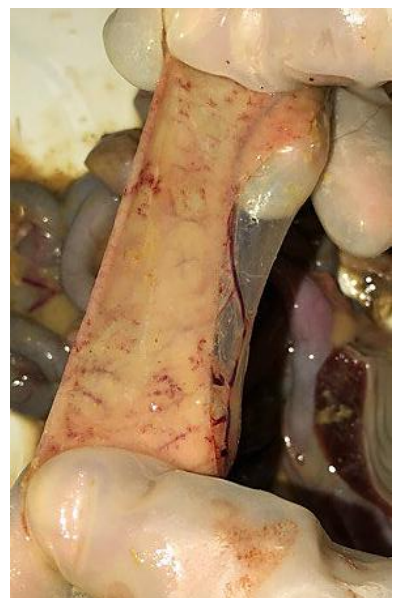

Puc. 17. Тонкий отдел кишечника курицы: подострый катар, множественные геморрагии на слизистой

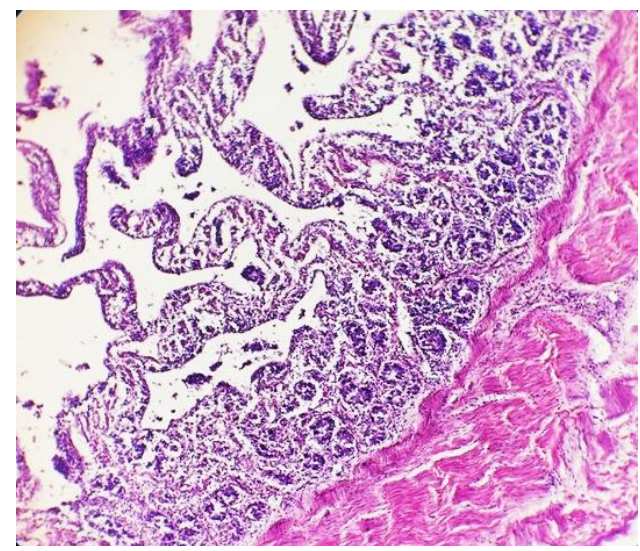

Рис. 18. Тонкий отдел кишечника курицы: инфильтрация слизистой неопластическими лимфобластами (окраска гематоксилином и эозином; × 400)

При макро- и микроскопическом исследовании сердца в 90 \% случаев выявлялись серозная атрофия подэпикардиального жира, свидетельствующая о крайней стадии алиментарного истощения, острая застойная гиперемия коронарных сосудов, острая застойная гиперемия миокарда (45,45\%), дифффузная и очаговая зернистая и зернисто-жировая дистрофия (90\% случаев), острая дилатация правых сердечных полостей (63,6 \%) (рис. 19).
При гистологическом исследовании в миокарде трупов всех птиц обнаруживались признаки очагового венозно-капилярного полнокровия, зернистой дистрофии кардиомиоцитов, а также множественные пролифераты незначительных размеров, состоящие из скоплений неопластических лимфобластов и пролимфоцитов, локализующихся между кардиомиоцитами (рис. 20). 


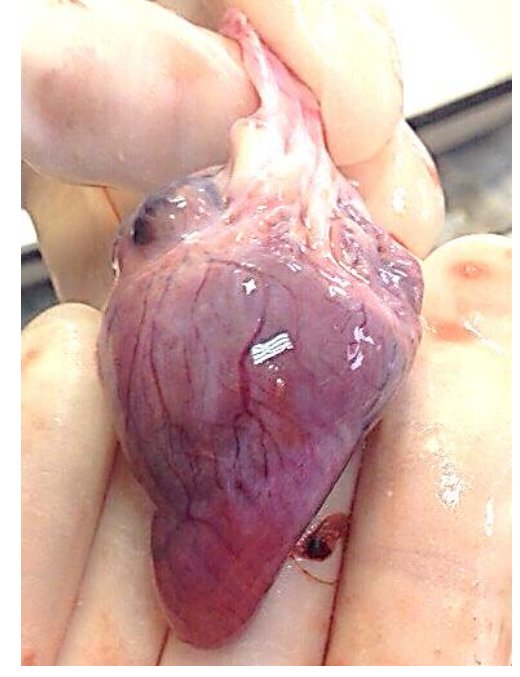

Puс. 19. Миокард курищы: атрофия подэпикардиального жира, гиперемия коронарных сосудов, белковая дистрофия миокарда

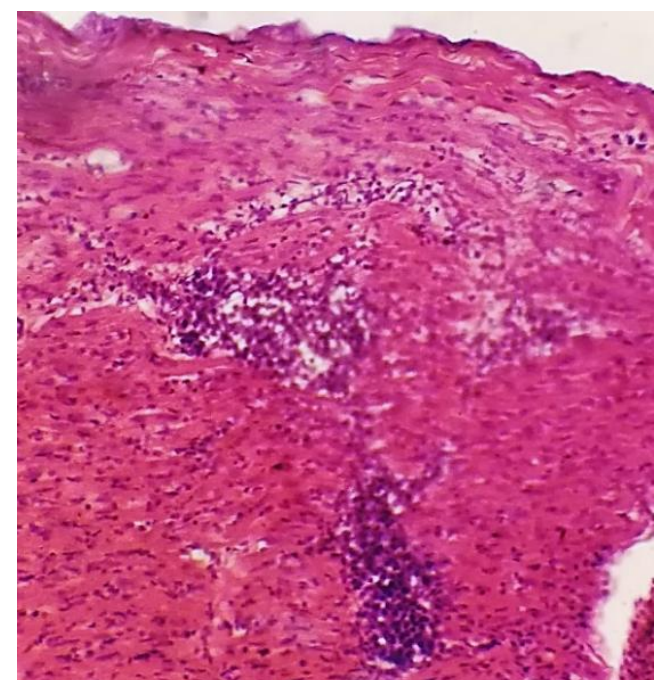

Puс. 20. Миокард курищы: белковая дистрофия, скопления неопластических лимфоидных клеток (окраска гематоксилином и эозином; × 400)

При исследовании органов репродуктивной системы у 63 \% кур выявлялись множественные очаговые опухолевые разрастания в яичнике, а также дифффузные изменения в яйцеводе: яичник значительно увеличен в объеме, серобелого цвета, поверхность органа бугристая, на разрезе опухолевые узлы «саловидные», гладкие, фолликулы - в состоянии атрофии, уменьшены в размерах, серого цвета, что обуславливало при жизни птицы резкое снижение яйценоскости. У всех исследуемых трупов кур (100\%) в яйцеводе устанавливались признаки острого катара - стенка органа утолщена в 1,5-2,5 раза, ригидна, серо-белого цвета, покрыта значи- тельным количеством мутной слизи. При исследовании семенников у обоих петухов выявлялись признаки диффузного разрастания опухолевой ткани - органы увеличены в размерах, сосуды - в состоянии острой гиперемии, структура - однородная, рисунок ткани стерт, консистенция мягкая, соскоб с поверхности разреза обильный полужидкий, цвет органа - молочнобелый (рис. 21).

Гистологическое исследование тканей яичника и яйцевода кур показало наличие очаговых опухолевых образований, состоящих из лимфобластов и пролимфоцитов, преимущественно локализующихся в интерстициальной ткани кор- 
кового и мозгового слоев яичника, сопровождающееся спадением и фррагментацией эластических волокон, уменьшением количества кровеносных сосудов, особенно в корковом слое. В тканях яйцевода наблюдалось наличие диффузных инфильтратов, локализующихся преимущественно в рыхлой соединительнотканной основе собственной пластики и подслизистом слое его стенки, также выявлялась картина ост- рого десквамативного катара слизистой всех отделов. В семенниках наблюдалась дифффузная инфильтрация рыхлой волокнистой соединительной ткани оболочек извитых семенных и прямых канальцев лейкозными недиффреренцированными клетками, при этом наблюдалось резкое уменьшение количества клеток сперматогенного эпителия (рис. 22).

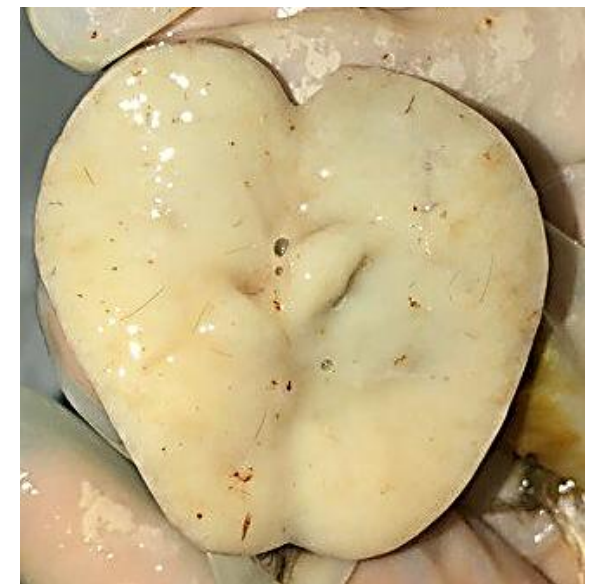

Puc. 21. Семенник петуха (орган на разрезе): гиперемия сосудов, нарушение рисунка тканевого строения, отсутствие структуры органа

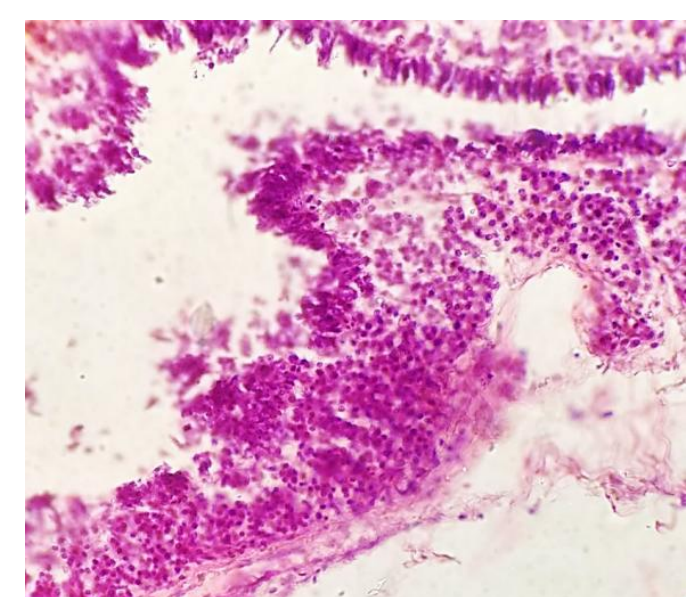

Puc. 22. Яйцевод курицы: инфильтрация бластными лимфоидными клетками слизистой оболочки, десквамативный катар (окраска гематоксилином и эозином; × 400)

На основании проведенного исследования можно сделать вывод, что патогномоничными патоморфологическими признаками лимфоидного лейкоза у кур являются диффрузные и очаговые разрастания слабодифференцированных лимфоидных клеток - лимфобластов и пролимфоцитов, имеющие, по сравнению со зрелыми формами, более крупные размеры, ядра, окрашивающиеся светлее, с сетчатой хроматиновой структурой и хорошо визуализирующимся ядрышком, и большее, по сравнению со зрелыми лимфоцитами, количество цитоплазмы с заметным перинуклеарным просветвлением. Очаги неопластических пролифератов выявлялись в $100 \%$ случаев в ткани фабрициевой бурсы как на макро-, так и на микроуровне, а также в тех 
органах, в тканях которых в норме присутствует значительное количество клеток мононуклеарно-макрофагальной системы - печени, селезенке, почках, причем в печени и почках преимущественно наблюдались узелковые и крупноочаговые поражения, которые выявлялись у $100 \%$ птиц, в селезенке в большинстве случаев поражения характеризовались картиной спленомегалии, при этом разрастания лейкозной ткани макроскопически выявлялись только у $27 \%$ птиц, а микроскопическая картина соответствовала диффузному поражению. Характерными морфологическими признаками лимфоидного лейкоза птиц также являются поражения сердца, легких и органов репродуктивной системы, выявляющиеся у 100 \% птиц и характеризующиеся макроскопическими изменениями в виде глубоких дистрофических и воспалительных процессов, мелких геморрагий, при этом неопластические пролифераты выявлялись в большинстве случаев исследования только на микроскопическом уровне, что подтверждает значимость и необходимость гистологического исследования тканей для достоверной диагностики заболевания, однако патогномоничным для лимфоидного лейкоза макроскопическим изменением трубчатых органов можно считать значительное утолщение их стенки, ее ригидность и специфическое бело-желтое окрашивание.

Патоморфологическая диффференциальная диагностика лимфоидного лейкоза птиц от сходного с ним по макро- и микроскопической картине изменений заболевания вирусной этиологии - болезни Марека была проведена на основании выявления у всех трупов птиц выраженных опухолевых разрастаний в фабрициевой бурсе, отсутствия в составе лейкозных пролифератов зрелых форм лимфоцитов - малых лимфоцитов, клеток с компактным ядром и незначительным количеством цитоплазмы в виде узкого ободка, а также клеток различной степени зрелости - плазмоцитов, гистиоцитов, ретикулоцитов. Важными патоморфологическими признаками лимфоидного лейкоза являются отсутствие опухолевых разрастаний в тазобедренных и плечевых нервных стволах, скелетной мускулатуре, изменения цвета радужной оболочки и формы зрачка в результате инфильтрации ее мононуклеарными клетками и полибла- стами, характерные для болезни Марека. Результаты анализа анамнестических данных больной птицы также являются характерными для лимфоидного лейкоза: отсутствие клинических симптомов в виде нервных явлений - парезов и параличей, хроническая форма течения болезни, пик заболевания у всех особей отмечался в возрасте 13-15 месяцев.

Заключение. Таким образом, можно заключить что при осуществлении патоморфологической диагностики лимфоидного лейкоза у птиц необходима комплексная оценка как патологоанатомических и патогистологических, так и анамнестических данных, при этом основополагающими критериями в постановке диагноза являются возраст птицы старше 12 месяцев, хроническое течение, отсутствие нервных явлений в анамнезе, увеличение размеров печени при клиническом осмотре, выявление опухолевых разрастаний в фабрициевой бурсе, печени, почках, спленомегалия и клеточный состав опухолевых инфильтратов, представляющих собой очаги пролиферации слабодиффференцированных лимфоидных клеток.

\section{Литература}

1. О распространении вируса лейкоза птиц в птицеводческих хозяйствах Российской Федерации / В.А. Плотников, Т.В. Гребенникова, Е.К. Дудникова [и др.] // Сельскохозяйственная биология. 2013. № 6. C. 36-42.

2. Исследование птицы на наличие виру-са лейкоза методом ПЦР / Т.В. Гребенникова [и др.] // Птица и птицепродукты. 2003. № 6. C. 35-37.

3. Bhutia L.D., Singh Y. Damodar Occurrence of lymphoid leukosis in poultry population of Mizoram // Indian Journal of Veterinary Pathology. 2017. Vol. 41(3). P. 228-231.

4. Soujanya S, Lakshman M., Madhuri D. Occurrence of lymphoid leukosis in chicken // The Pharma Innovation Journal. 2019. Vol. 8(1). P. 159-162.

5. Салаутина С.E., Салаутин В.В. Сравнительная оценка патоморфологических изменений при нейролимфоматозе и лейкозе кур // Ученые записки Казанской государствен- 
ной академии ветеринарной медицины им. Н.Э. Баумана. 2015. № 3. Т. 223. С. 160-162.

6. Payne L.N., Venugopal K. Neoplastic diseases: Marek's disease, avian leukosis and reticuloendotheliosis // Revue scientifique et technique (International Office of Epizootics). 2000. Vol. 19. P. 544-564.

7. Payne L., Nair V. The long view: 40 years of avian leukosis research // Avian Pathology. 2012. Vol. 41(1). P. 11-19.

8. Вахрушева Т.И. Особенности патоморфологических проявлений хронического миелоидного лейкоза у кур // Вестник КрасГАУ. 2020. № 1 (154). C. 62-75.

\section{Literatura}

1. O rasprostranenii virusa lejkoza ptic $v$ pticevodcheskih hozjajstvah Rossijskoj Federacii / V.A. Plotnikov, T.V. Grebennikova, E.K. Dudnikova [i dr.] // Sel'skohozjajstvennaja biologija. 2013. № 6. S. 36-42.

2. Issledovanie pticy na nalichie virusa lejkoza metodom PCR / T.V. Grebennikova [i dr.] // Ptica i pticeprodukty. 2003. № 6. S. 35-37.
3. Bhutia L.D., Singh Y. Damodar Occurrence of lymphoid leukosis in poultry population of Mizoram // Indian Journal of Veterinary Pathology. 2017. Vol. 41(3). R. 228-231.

4. Soujanya S, Lakshman M., Madhuri D. Occurrence of lymphoid leukosis in chicken // The Pharma Innovation Journal. 2019. Vol. 8(1). R. 159-162.

5. Salautina S.E., Salautin V.V. Sravnitel'naja ocenka patomorfologicheskih izmenenij pri nejrolimfomatoze i lejkoze kur // Uchenye zapiski Kazanskoj gosudarstvennoj akademii veterinarnoj mediciny im. N.Je. Baumana. 2015. № 3. T. 223. S. 160-162.

6. Payne L.N., Venugopal K. Neoplastic diseases: Marek's disease, avian leukosis and reticuloendotheliosis // Revue scientifique et technique (International Office of Epizootics). 2000. Vol. 19. R. 544-564.

7. Payne L., Nair V. The long view: 40 years of avian leukosis research // Avian Pathology. 2012. Vol. 41(1). R. 11-19.

8. Vahrusheva T.I. Osobennosti patomorfologicheskih projavlenij hronicheskogo mieloidnogo lejkoza u kur // Vestnik KrasGAU. 2020. № 1 (154). S. 62-75. 